\title{
РЕЦЕНЗIї
}

DOI https://doi.org/10.32837/pyuv.v0i5(34).668

\author{
Я. В. Лазур \\ orcid.org/0000-0002-7520-7167 \\ доктор юридичних наук, професор, \\ декан юридичного факультету \\ Ужгородського національного університету
}

\section{РЕЦЕНЗІЯ НА МОНОГРАФІЮ Р. О. СТЕФАНЧУКА, І. М. МИЩАКА ТА А. О. ЯНЧУКА «СТАНОВЛЕННЯ Й РОЗВИТОК НАРОДОВЛАДДЯ НА УКРАЇНСЬКИХ ЗЕМЛЯХ ${ }^{1}$}

Визнання народу основним носієм влади є ключовою ознакою демократичності сучасних правових держав. Водночас таке розуміння усталилося порівняно нещодавно, а до того інститут народовладдя пройшов тривалу еволюцію, виборовши своє визнання на законодавчому рівні шляхом численних народних повстань і революцій.

Народовладдя в Україні також має давню і славну історію, сягаючи своїм корінням перших протодержавних утворень. З утворенням східнослов'янської держави - Київської Русі - пов’язують і перші праукраїнські форми народовладдя - народні збори і віча.

Автори рецензованої монографії розробили власну періодизацію становлення й розвитку інституту народовладдя, пов'язавши її з основними віхами державотворення та входження українських земель до складу інших держав. Водночас заслугою авторів $€$ те, що в кожному періоді вони зосереджували увагу не на інститутах народовладдя загалом, а на досвіді участі українців у діяльності зазначених інститутів. Таким чином, навіть у період бездержавності простежується саме український контекст, який справедливо обгрунтовується як вагомий досвід, що потім використовувався в розбудові суто національних інститутів народовладдя під час здобуття державності на тому чи іншому етапі.

Заслуговує на увагу докладний аналіз авторами правових актів, які закріплювали принципи народовладдя. Особливо підкреслюється роль Конституції Пилипа Орлика 1710 року, яка була першим у світовій правотворчій традиції Основним Законом, що встановив систему стримувань і противаг у діяльності владних інститутів та право народу на здійснення влади шляхом формування як представницьких інститутів, так і безпосереднього обрання вищих посадових осіб. I хоча норми зазначеного документа не були втілені

${ }^{1}$ Становлення й розвиток народовладдя на українських землях : монографія / Р.О. Стефанчук, I.М. Мищак, А.О. Янчук. Одеса : Видавничий дім «Гельветика», 2020. $156 \mathrm{c}$. в життя, вони стали підгрунтям для подальших політико-правових ідей, які розвивалися в епоху входження українських земель до складу Російської та Австро-Угорської імперій.

Ідея козацького народоправства і демократичних традицій підживлювала українську еліту упродовж тривалого часу після скасування гетьманства й автономії українських земель, покликаючи до життя численні таємні й напівлегальні гуртки та товариства, які виробляли власні моделі державного устрою майбутньої Української держави. Саме завдяки цьому, справедливо доводять автори дослідження, стало можливим українське національне відродження та швидкий розвиток державних інститутів в умовах Української революції 1917-1921 років.

Проголошення автономії, а далі й незалежності України в 1917-1918 роках було реалізоване завдяки послідовній нормотворчій роботі щодо забезпечення легальності та легітимності влади. Водночас тогочасні державники цілком усвідомлювали необхідність законодавчих гарантій народовладдя, що було гарантоване Конституцією УНР 1918 року й іншими конституційно-правовими актами, зокрема універсалами Української Центральної Ради як найвищого представницького органу українського народу, який був визнаний спочатку Тимчасовим урядом, а згодом також іноземними державами.

У монографії чітко простежується тяглість державотворчих традицій українського народу та інститутів народовладдя, які, за твердженням авторів, еволюціонували та розвивалися від одного періоду до іншого, пройшовши шлях від військової демократії й народних зборів до представницьких органів парламентського типу.

Окрема увага приділена аналізу радянської державності та 3'ясуванню особливостей тогочасних представницьких форм народовладдя. Автори на основі норм конституцій УСРР 1919 та 1929 років доводять відхід радянської влади від ідеї народовладдя всупереч власним задекларованим принципам, що проявилося в обмеженні політичних прав 
широких верств населення та встановленні однопартійної системи, яка була визнана на конституційному рівні. Навіть формальне зрівняння громадян у правах після схвалення Конституції УРСР 1937 року та створення єдиного законодавчого органу - Верховної Ради - не призвели до повноцінного відновлення інститутів представницької влади та безпосереднього здійснення влади народом. Подальше закріплення в Конституції УРСР 1978 року принципів народовладдя, народного контролю тощо носило більше формальний характер, оскільки навіть на рівні Конституції було закріплено керівну роль у державі Комуністичної партії.

Авторами доведено, що повноцінний розвиток інституту народовладдя в Україні став можливим лише після проголошення державної незалежності й закріплення його основних засад, які від- повідають світовим демократичним традиціям, у Конституції 1996 року. Разом із тим механізми реалізації права народу на здійснення влади потребують розширення й подальшого удосконалення, що стало одним і пріоритетів діяльності Президента та Верховної Ради. Розробка таких механізмів неможлива, на переконання авторів монографії, без урахування історії становлення та розвитку інституту народовладдя на українських землях, який має власну специфіку.

У цілому монографія Р. О. Стефанчука, I. М. Мищака та А. О. Янчука «Становлення й розвиток народовладдя на українських землях" є цілісним та завершеним науковим дослідженням, яке, на нашу думку, буде корисним не лише історикам права, а всім, хто цікавиться питаннями народовладдя. 